\title{
UTILIZING VIDEOCAST: FOSTERING STUDENTS’ LISTENING COMPREHENSION
}

\author{
Muhammad Syahruddin Nawir \\ Universitas Islam Negeri Alauddin Makassar \\ syahruddin.nawir@gmail.com
}

\begin{abstract}
Listening has an important role in communication which is applied in foreign language classroom and it is considered as necessary skill because it has an essential role in facilitating learners to master English proficiency. The aims of this research were to find out the extent to which videocast improves listening comprehension of the fourth semester students of Makassar Islamic University and the students' perceptions toward the utilization of videocast in teaching and learning activities. This research was carried out in the fourth semester students of English Department of Makassar Islamic University. The method used was quasi-experimental design with pre-test, eight meetings of treatment, and post-test. The data were collected using two kinds of research instruments: listening test and questionnaire. The data were then analyzed by means of statistical analysis through the independent sample $\mathrm{t}$ test and the frequency of questionnaire. The result showed that the independent $t$-test which compared the students' score on post-test revealed a value of $\mathrm{p}<0.05$. It means there is a significant difference between listening comprehension of the students who were taught by utilizing videocast and the students who were not taught by utilizing videocast. Furthermore, the analysis of questionnaire indicated that the students' perceptions toward the utilization of videocast were very positive. It can be concluded that utilizing videocast improves significantly students' listening comprehension.
\end{abstract}

Keywords: Videocast, Listening Comprehension, Students' perceptions

\section{A. INTRODUCTION}

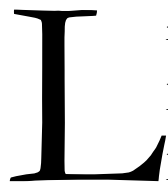
istening has an important role in communication which is applied in foreign language classroom. Thus, listening is one of the language skills which English learners have to learn. Cahyono (1997), stated that listening is considered as necessary skill because it has an essential role in facilitating learners to master Englis9

$\mathrm{h}$ proficiency. Skill in listening, for example, can help learners participate well in oral communication, since communication cannot take place successfully if the message is not understood.

Somehow, acquiring EFL listening skill becomes difficult task for any learners. As Brown (1995), stated that listening comprehension is difficult for foreign or second language learners simply because aspects of the language are difficult for learners. One aspect, which still appears to be strangely neglected, is the question of the intrinsic cognitive difficulty of the text. Cognitive difficulty is seen in terms of factors that make some central listening process easier or difficult to perform such as identify information, search memory for information, file or store information, and use the information in some way. 
In addition, Underwood (1989) also mentioned some potential problems which frequently occur in listening. For instance, lack of speed control on speakers' utterance, unable to repeat speakers' utterance, have limited vocabularies, and inability to concentrate. Outside factor may also affect such as the quality of the recording or the classroom condition.

In this case, based on the result of observation at Makassar Islamic University, the students still have difficulties to get the objectives of the study successfully. The results showed that the students were not provided with pre-listening activities to raise their attention in listening activities. The students got difficulties in understanding native speakers' speech and could not control the speed of the speaker's speech, and most students were not very enthusiastic in listening activities. They just listened to the cassette or CD that provided limited authentic and old fashioned material so the participant were not actively involved in listening classroom activities and also in selecting the material or self-learning style.

Somehow, to outgrow the problems in the listening class activities, it needs another alternative to encourage the students to be better in listening. Then, factors contribute to the fruitfulness of listening instruction is the application of media instruction in presenting the listening activities. Some media such as the use of film, TV program, song, podcast can help the students to overcome their problems in the listening comprehension. One of them is videocast.

Videocast uses the combination of three media (audio, visual, and technology) that accessed through the internet can motivate the learners to learn. Erben et al (2009), point out that the students can get comprehension or understand the meaning of the message through other speakers' body language and facial expressions. The three views (audio, visual, and technology) mentioned above could be achieved from the videocast.

Thus, taking everything into consideartion, the adequate of helpful listening activities must be given. Thereby, this study aimed to improve the students' listening comprehension by utilizing videocast in the classroom activities.

\section{B. REVIEW OF LITERATURE}

All form of communication can be manifested by authentic matter. It may in the form of written document, audio podcast, or video of commerce. Hiring authentic materials aims to provide real context and illustration. So the students can experience the real life situation that can assist them to focus on the language skill the need (Gardner and Miller, 1999). Therefore, videocast as authentic materials that provides real communications from target language can motivate students to learn language skill especially for listening practice. 
Running image such as video can be a very worthy means for language learning. The edges this tool provides samples of real-life communication, model of interaction, and promoting language acquisition. Mirvan (2013) declared that similar situation on real life played on the video can raise students' motivation since it promotes a variety of circumstances. Christopher and Ho (1996) viewed another rationale why this is so because the reason of entertaining. Sounds, gestures, moods, and the setting elements invent enjoyable experience by the students who enjoy the scene. All things considered, videocast that presents audio and visual elements might be used as a language learning aids for the students.

Yumarnamto \& Wibowo (2008) conducted a research under the title "Podcast and Videocast from the Internet to Improve Students' Listening Skill”. The Classroom Action Research (CAR) was implemented in the odd semester of the 2006/2007 academic year. The main idea of the CAR implementation was to make the students access podcasts and videocasts to develop their listening comprehension. The findings of the CAR suggest that the students show a significant improvement in their listening skill. The average score for the course is 71.78 - which is better compared to the average score of the same course in the last two semesters prior to the CAR (64.3).

Cross (2009) conducted a research under the title, "Effect of Listening Strategy Instruction on News Videotext Comprehension". He held a study for Japanese EFL learners' found that technological advances mean the use of videotexts can develop listening skill in language learning setting. The result indicated a significant improvement for the experimental group which received listening strategy instruction by BBC news videotext.

Syamsudarni (2010) conducted a research under the title, "The Use of Videocast to Improve Listening Skill of English Department Students of STAIN Palopo”. This study was conducted in two cycles by following the procedure of the action research i.e. planning, implementing, observing, and reflecting. The findings of the study show that the use of videocast can improve the students' listening skill.

The results of the previous studies indicate that the use of video have positive value in teaching and learning of listening. The previous studies concerned with increasing students' participation and interest in learning English by using video in various techniques. However the study that focuses on the use of video in the form of videocast downloaded from internet and implemented in the classroom by three stages activity (pre listening, whilst listening, and post listening) has not been conducted yet. Besides, none of the previous studies conducted a research by quasi-experimental design which compare students' achievement in listening 
comprehension between experimental and control group in university levels. Therefore, this study is worth to be conducted.

\section{METHODOLOGY}

\section{Research Design}

Quasi-experimental design with nonequivalent control group design was used in this investigation. The experimental group was treated by utilizing videocast otherwise the control group was not or treated by conventional method.

\section{Population and Sample}

The fourth semester students of English Department of Makassar Islamic University in academic year 2015/2016 became the population in this study by 80 students. From the population, cluster random sampling technique was used to choose the sample by taking two groups randomly which represent as experimental and control group. Therefore, 40 students were chosen consisting of 20 students for experimental group and 20 students for control group.

\section{Procedures of Collecting Data}

Listening tests and questionnaire are used as the research instrument for collecting data in this research. The listening tests aimed to assess the improvement of students' listening comprehension while the questionnaire was used to find out the students' perceptions on utilizing videocast in teaching and learning listening comprehension.

In data retrieval, both experimental and control group were given pretest to measure the students' listening comprehension. After that, the experimental students were treated by utilizing videocast in the class for eight meetings. Then both groups were given the posttest to know the students' achievement. Therefore, Statistical Product and Service Solution (SPSS) version $20 \mathrm{IBM}$ was used to analyze quantitatively the data collection. Moreover the questionnaire was measured by classifying the sample responses into five point of rating scale by using the Likert Scale measurement.

\section{FINDINGS AND DISCUSSIONS}

\section{Findings}

To start with, the result of pretest for both groups indicated that they were in "fair level" in which the mean score of experimental group was 48.30 and 48.80 for control group. Nevertheless, the posttest result showed significant improvement especially the experimental 
group by gaining the mean score of 70.50 that classified as "good level" whiles the control group was only 59.40 that classified as "fair level".

The probability value of Independent-sample t-test for pretest was 0.856 which is higher than $\alpha=0.05$ that means there was no significant difference for both groups. On the other hand, the probability value of posttest was 0.000 which is smaller than $\alpha=0.05$ which means that there was a significant different between experimental and control group. On account of this result, the experimental group had significant improvement. The data collection from the questioner also showed that utilizing videocast gained positive responses which was proven by the mean score of the students' perception classified as "Very Positive Perception" with the interval range $=65$.

\section{Discussion}

Applying media positively supports the success of the teaching and learning activities. Videocast as one of technological media has a good contribution in motivating students to learn. This was proved by the students' perceptions on the use of Videocast. They became enthusiastic to learn. The study which was conducted by Yumarnamto \& Wibowo (2008) and Hager (2009), found that the use of videocast can make students highly motivated and enthusiastic to learn. Similarity, Kusumarasdyati (2004), found that the advance of videos as a teaching instrument can motivate the member of class and engaged them in various activities in the target language.

The use of videocast which is the combination of audio, visual, and technological tools implemented in the classroom has positive achievement in motivating students to learn in order to get successful of teaching and learning process (Santoso, 2008). It is also supported by Jonassen et al (2003), who stated that the use of technology can facilitate learning activity. Furthermore, the research on visual technology conducted by Reid (2002), found that playing digital video can enhance students' speaking and listening skills and also increase pupils' motivation. Videocast is virtually energizing, the audio and the play image lively arrests our concern. As Willis (1983), agreed that video is an intermediary that can help pupils to interpret the visual interaction effectively. Additionally, videocast also provides students' occasion to observe the target language.

Videocast as technological tools to intensify students' listening comprehension is also supported by the implementation of three activities: pre-listening, whilst-listening, and postlistening. Therefore, videocast which considered as learning media is quite important to present in the classroom. Stempleski \& Tomalin (1990), stated that some factors that 
videocast can help the students improve their listening skills are through communication, non-verbal aspects of communication, motivation, and cross cultural comparison.

A videocast played in the classroom make students ready to express their ability to communicate in the target language. Body gesture, expression, and moving as non-verbal aspect of communication can also help the students to interpret the language in the videocast scene. From all the combination including visuals and sounds, the videocast serves the language extensively. Moreover, videocast also provides the way of people of target language interact so the students can learn cross-cultural equation in the class.

Taking everything into consideration, the utilization of videocast improves both the students' listening skill and their involvement in the learning process. Therefore, as shown in this investigation, videocast can be used whether in the classroom as intensive listening or outside the class as extensive listening.

\section{E. CONCLUSIONS}

Utilizing videocast can increase the students' listening comprehension and also develop their entanglement during learning process. Videocast is especially interesting for English learners as it provides to get access to authentic listening sources. Students can take advantage of videocast for listening comprehension exercises, as a means of practicing conversation based on speakers' reaction in the videocast. So, utilizing videocast contributed significantly to improve students' listening comprehension. This research also indicated that utilizing videocast in teaching listening gained very positive responses from the students.

\section{REFERENCES}

Brown G. (1995). Speakers, Listeners and Communication: Explanation in Discourse Analysis. Cambridge: Cambridge University Press.

Cahyono B. Y. (1997). Pengajaran Bahasa Inggris: Teknik, Strategi, dan Hasil Penelitian. Malang: IKIP Malang.

Christopher, E., \& Ho, S. (1996). Lights, camera, action: exploring and exploiting films in selfaccess learning. In R. Permberson, E. S. L. Li, W. W. F. Or, \& H. D. Pierson (Eds.). Taking control: Autonomy in language learning (pp. 185-200). Hong Kong: Hong Kong University Press

Cross, Jeremy. (2009). Effect of Listening Strategy instruction on News Videotext Comprehenion. Language Teaching Research. 13(2): 151-176. 
Erben T., Ban, R. \& Castaneda, M. (2009). Teaching English Language Learners through Technology. New York: Routledge.

Gardner, D., \& Miller, L. (1999). Establishing self-access: From theory to practice. Cambridge: Cambridge University Press.

Hager P. (2009). Vodcasts Help Students Understand Wide Variety of Spoken Norwegian. Department of Scandinavian Studies (online) accessed on May $4^{\text {th }} 2016$. Available from: http://pehager@wise.edu

Jonassen D.H., Howland J., Moore J., \& Marra R.M. (2003). Learning to Solve Problems with Technology: A Constructivist Perspective ( $2^{\text {nd }}$ ed.). Upper Saddle River: Merrill Prentice Hall.

Kusumarasdyati. (2004). Listening, Viening and Imagination: Movies in EFL classes. Proceeding of the $2^{\text {nd }}$ International Conference on Imagination and Education; 2004 July 14-17; Vancouver: Canada.

Mirvan, X. (2013). The advantages of using films to enhance student's reading skills in the EFL classroom. Journal of Education and Practice, 4(13), 62-66.

Reid M. (2002). Evaluation of Becta digital Video Pilot Project. Report on Educational Research on the Use of ICT in Learning and Teaching English-a selection of abstracts and Further Sources (online) accessed on March $7^{\text {th }}$, 2016. Available from: http//www.becta.ort.uk/research/reports/digitalvideo.htm

Santoso. (2008). Podcards: Authoring E-Learning Resources in Digital Age of English Teaching and Learning. Proceeding of the Asia TEFL Conference Bali; 2008; Bali, Indonesia.

Stempleski S. \& Tomalin B. (1990). Video in Action: Recipes for Using Video in Language Teaching. New York: Prentice Hall.

Syamsudarni. (2010). The Use of Videocast to Improve Listening Skill of English Department Students of STAIN Palopo. Unpublished Thesis. Malang: Graduate Program - State University of Malang.

Underwood M. (1989). Teaching Listening. London and New York: Longman.

Ur P. (1996). A Course in Language Teaching. Cambridge: Cambridge University Press.

Willis J. (1983). Video Application in English Language Teaching. The Role of the Visual Element in Spoken Discourse: Implications for the Exploitation of Video in the EFL Classsroom. In J. McGovern (Ed.). Oxford: Pergamon.

Yumarnamto M. \& Wibowo B. H. S. (2008). Podcasts and Videocasts from the Internet to Improve Students' Listening Skill. Proceeding of Asia TEFL Conference Bali; 2008; Bali, Indonesia. 